\title{
A TORMATERMESZTÉS SZEREPE A HAJDÚSÁGBAN
}

\author{
Harangi-Rákos Mónika - Zilahi Kristóf - Novák Norbert - \\ Oláh Judit - Popp József
}

\begin{abstract}
Absztrakt: A mezőgazdaság, ezen belül a növénytermesztési ágazat jelentős szerepet játszik, hiszen mind a növényi élelmiszerek alapját, mind pedig az állati takarmányozásra és állattartásra felhasználható terményeket, valamint a növényi maradványokat a növénytermesztés szolgáltatja. Kutatásunk során megállapítottuk, hogy a tormatermesztéssel elérhető bevételek függenek a piaci áraktól, a termés hozamától és annak minőségétől. A termelők árelfogadóak, így bevételük nagysága a termelt mennyiségtől és minőségtől függ. A torma termesztése szerteágazó munkaszervezéssel, számos munkafázissal és magas költségráfordítással jár. A torma termesztése során jelentkező kiadások legjelentősebb hányadát a személyi jellegú költségek jelentik. Megállapítható, hogy a tormatermesztés előtt nagy jövő állhat, mivel a termelők lelkesek és még számos technológiai fejlesztési lehetőség van az ágazatban, mellyel a magas élőmunka-igénye csökkenthetö lenne.
\end{abstract}

\begin{abstract}
The crop production plays important role in agriculture as food and feed. During our research, we realised that income of the horse-radish production depends on the market prices, yield and quality of products. The producers are price takers, so the amount of their income depends on the quantity and quality of harvested products. The largest share of production costs is the labour costs. Horse-radish production needs diverse organized labour with several phases and high expenses during the production period. As a summary we can highlight that the horse-radish production has perspectives because the farmers are enthusiastic, they are engaged to the horseradish production and there are several possibilities in this sector to decrease labour cost.
\end{abstract}

Kulcsszavak: torma, mezőgazdaság, vidéki térség

Keywords: horse-radish production, agriculture, rural area

\section{Bevezetés}

Magyarországon meghatározó jelentőségű a mezőgazdaság. A mezőgazdaság bruttó kibocsátása 2015-ben 2454 milliárd forint volt, melyből 1428 milliárdot a növényi termékek (58\%), az állatok és az állati termékek 854 milliárdot (35\%), a fennmaradó 172 milliárdot $(7 \%)$ pedig a mezőgazdasági szolgáltatások és egyéb tevékenységek adták. A növénytermesztésen belül a gabonafélék és az ipari növények kibocsátása a legnagyobb, míg a húskészítményeknél a baromfi és tojás a meghatározó, ezt követi a szarvasmarha és nyers tej (KSH, 2016a). Ezek aránya az 1980-as években kiegyenlített volt (Németi, 2003), a rendszerváltást követően azonban a két stratégiai ágazat egymáshoz viszonyított arányában elmozdulás volt megfigyelhető. Az állattenyésztés bruttó kibocsátáson belül képviselt részaránya folyamatosan csökkent, melynek hatására a növénytermesztés részaránya épp ellentétes, jelentősen növekvő tendenciát mutatott (Kapronczai, 2011). Miután hazánk az Európai Unió tagjává vált, a folyamat felgyorsult és csak az utóbbi pár évben volt tapasztalható kisebb mértékủ stagnálás.

A növénytermesztési ágazaton belül jelentős szerepet tölt be a zöldség- és gyümölcságazat. Hazánk földrajzi, éghajlati, talajtani és más adottságai a zöldségés gyümölcstermelés számára megfelelö körülményeket biztosítanak. Ezek az 
ágazatok úgy tudnak jelentős értéket előállítani, hogy közben a szántóföldi területeknek csak egy kisebb hányadát kötik le (Magda, 2002).

Hajdú-Bihar megyében, az országos trendekhez hasonló módon, a gabonanövények és az olajnövények termesztése adja a növénytermesztés legnagyobb részarányát. $\mathrm{E}$ növénytípusok magas gépesítettségi arány mellett termeszthetők, élőmunka igényük elhanyagolható. A Hajdúság kedvező talajtani és ökológiai adottságai lehetővé teszik számos más növényfaj termesztését. E földrajzi területen több olyan zöldségfélét is termesztenek, melyek máshol nem, vagy csupán elhanyagolható mennyiségben teremnek. Ilyen növény például a torma, melyet rendkívül magas élőmunka-ráfordítással lehet termeszteni. A torma a gyökérzöldségek egyike, termesztésének a föterméke a rizóma (a gyökér). A torma termőterülete Hajdú-Bihar megye területén belül is néhány egymással szomszédos településre korlátozódik. E települések jelentik azt a Debrecen környéki összefüggő tormatermesztő területet, a hajdúsági tormatermesztő tájat, mely Magyarországon egyedülálló. Az itt megtermelt torma magáról a termesztő körzetről kapta a hajdúsági torma elnevezést. Az érintett települések lakosai számára a növény termesztése elsődleges és/vagy kiegészítő jövedelemforrást jelent.

\subsection{A növénytermesztés jelentösége Magyarországon}

Magyarország területe 9,3 millió hektár, melynek közel 80\%-a termőterület 2016ban (KSH, 2016b). A termőterület 57\%-a (5,4 millió hektár) a mezőgazdasági terület, mely a szántó, konyhakert, szőlő, gyümölcsös és gyep művelési ágakat tartalmazza (KSH, 2016c). A mezőgazdasági területek arányának csökkenő tendenciája figyelhető meg az elmúlt időszakban. A mezőgazdaságilag mủvelt terület $80 \%$-ot meghaladó részarányát a szántóterületek adják (KSH, 2016c), azonban ez az arány is folyamatos csökkenést mutat 2004 óta.

A vetésszerkezet nagyságrendileg változatlan az elmúlt 10 évben. 2015-ben a gabonafélék $66 \%$-ot tetettek ki, melyből a búza és kukorica 25-28\%-ot képviselt. $\mathrm{Az}$ olajnövények esetében a napraforgó $14 \%$, a repce aránya 5,4\% volt $(\mathrm{KSH}$, 2016a). 2,7 millió hektáron 14 millió tonna gabonát takarítottak be 2015-ben, ami az elmúlt öt évet vizsgálva növekedést (5\%-os) mutat. A kukorica betakarított mennyisége csökkent $8,6 \%$-kal az előző öt évhez képest. A napraforgó és a repce betakarított területe viszont növekedett. Míg a zöldségfélék termésmennyisége $3,4 \%$-kal nőtt, addig a gyümölcsfélék mennyisége $17 \%$-kal esett vissza.

Hazánkban a zöldségtermesztésre használt terület nagysága az elmúlt években 80-120 ezer hektár között váltakozott. Az uniós csatlakozás elötti években a betakarított termés 1,5-2,0 millió tonna között alakult. A zöldség termésmennyisége hosszabb éveken át csökkenö tendenciát mutatott, de 2010-től évente kisebb ingadozásokkal - bizonyos mértékü növekedés volt tapasztalható (KSH, 2016a).

Magyarország esetében nemzetgazdasági szempontból is jelentős szerepet tölt be a zöldség- és a gyümölcságazat. A zöldség-és a gyümölcstermesztési ágazatokat is magába foglaló kertészet a mezőgazdaság egyik meghatározó, hosszú időre visszanyúló tradíciókkal bíró ágazata. A termelés legfontosabb feladata a belföldi 
szükségletek kielégítésén túlmenően a felmerülő exportlehetőségek lehető legnagyobb mértékủ kiaknázása. A kertészeti ágazat annak ellenére is jelentős termelési értéket tud előállítani, hogy a mezőgazdasági területekből elég kis hányadot köt le. Ugyanakkor a kertészeti termelés jellemző tulajdonságai a nagy befektetési igény, az élőmunka iránti jelentős szükséglet és - az előző körülményektől aligha független módon - az egységnyi területen előállított nagy termelési érték (Magda, 2002).

Potori et al. (2008) munkájukban úgy mutatja be Magyarország kertészeti termelését, hogy a megfogalmazott észrevételek még napjainkban is teljes mértékben helytállóak. Magyarországon a kertészeti termelést két kialakult főbb modell jellemzi, melyek jelentősen eltérnek egymástól. A tőkehiánnyal küzdő gazdálkodók egy része ugyanis elavult módszerekkel termeszt, ennek eredményeként pedig az általuk elért terméshozam igen alacsony. A gazdálkodóknak egy másik, intenzív, szakszerü termesztési technológiát alkalmazó köre az európai országok átlagos szintjét is elérő terméshozamot produkál. A hazai átlaghozamok még mindig nem érik el az EU-tagállamok hasonló mutatóit, és emellett a magas minőségủ áruk aránya is alacsony. Ahhoz, hogy javulni tudjon a versenyképesség, feltétlenül növelni kell a hatékonyságot a vertikális integráció fejlesztésével (Takácsné György-Takács, 2016).

\subsection{Tormatermelés}

A torma kozmopolita növényként ismert, Európában, Ázsiában és az amerikai földrészen is megtalálható (Géczi, 2013). Az őshazája feltételezhetően a DélkeletEurópában van, a Fekete-tenger környékén (Haraszthy, 2005), de egyesek Ukrajnából származtatják (Géczi, 2013). A termesztése Európában Németországban indult meg a XV. században. Az itt kialakult genetikai vonalak megtalálhatóak a termesztő tájak jellegzetes tájfajtái között. Az első tormaszaporításról szóló magyarországi forrás 1664-ben Lippai János által készült. A legelső piacra történő termesztésről származó adatok a XIX. század elejéről állnak rendelkezésünkre (Pántya, 2000).

A torma már a 16. században ismert füszernövénye volt a magyar konyhának, azonban a XX. századra kis híján a feledés homályába merült. Az utóbbi években komoly elörelépés történt a magyar tormával kapcsolatban, amely napjainkra ismét előtérbe került. Megjelentek a konyhakész, üveges, poharas és tubusos kiszerelésủ tormakészítmények, melyek iránt egyre nagyobb fogyasztói érdeklődés tapasztalható hazánkban (Géczi, 2003). A torma egyike a legegészségesebb zöldségféléinknek. Míg a kezdetek során gyógynövényként és étkezési célra termesztették a tormát, később egyike lett azon ritka növényeinknek, melyeknek minden része hasznosítható (Haraszthy, 2005). A torma a népi gyógyászatban is előszeretettel alkalmazott növény, népszerüsége töretlen. Kimagasló a kálium és a C-vitamin tartalma (Pántya, 2000).

Az 1960-as évektől megnyíltak az exportlehetőségek a magyar torma előtt, méghozzá elsődlegesen a nyugat-európai piacok irányába. Az 1990-es években Magyarországon a tormát megközelítőleg 1600 hektáron termesztették, melyböl a 
hajdúsági termőtáj az összes tormaterület $75-80 \%$-át tette ki. A győr-mosonsoproni, valamint a dél-dunántúli termesztő tájon végzett termelési tevékenység azonban megtorpant, elsősorban a motiváció hiánya miatt, mivel a költséges egyéves termesztéstechnológia kézimunkaerő igényes ágazatnak tekinthető (Pántya, 2000). A magyar torma különleges édesnemességével és csípősségével vált keresetté a különböző piacokon (Géczi, 2009). A torma termesztésére használt termőterület az ezredforduló időszakára mintegy 2000 hektárral növekedett, és ekkorra tehető az egyetlen megmaradt magyarországi termelőkörzet, a Hajdúsági Tormatermesztő táj kialakulása (1. táblázat).

1. táblázat: A tormatermesztő tájat alkotó települések és azok fontosabb adatai, 2003

\begin{tabular}{|l|c|c|c|c|}
\hline \multicolumn{1}{|c|}{ Település } & $\begin{array}{c}\text { Tormát termelö } \\
\text { családok száma } \\
(\mathbf{d b})\end{array}$ & $\begin{array}{c}\text { Tormatermö } \\
\text { terület (ha) }\end{array}$ & $\begin{array}{c}\text { Tormater- } \\
\text { més (t) }\end{array}$ & $\begin{array}{c}\text { Aranykoro- } \\
\text { na érték }\end{array}$ \\
\hline Álmosd & 30 & 45 & 247,5 & 16,6 \\
\hline Bagamér & 325 & 370 & 2035 & 14,81 \\
\hline Debrecen & 110 & 140 & 770 & 15,56 \\
\hline Hosszúpályi & 15 & 15 & 82,5 & 14,3 \\
\hline Kokad & 45 & 70 & 385 & 16,04 \\
\hline Létavértes & 110 & 135 & 742,5 & 20,09 \\
\hline Monostorpályi & 25 & 30 & 165 & 15,08 \\
\hline Újléta & 263 & 336 & 1848 & 9,6 \\
\hline Vámospércs & 150 & 150 & 825 & 12,15 \\
\hline $\begin{array}{l}\text { Egyéb } \\
\text { települések }\end{array}$ & 52 & 64 & 352 & $9-11,5$ \\
\hline Összesen & - & 1355 & 7452,5 & - \\
\hline
\end{tabular}

Forrás: Haraszthy (2005) alapján saját szerkesztés

Hazánkban tormatermesztésre használt földterület nagysága több év átlagában 1600 hektárra tehető, ebböl a növényből hektáronként 7-10 tonna között ingadozó termésátlag érhető el. 2015-ben 1356 hektárnyi területen termesztettek tormát, ami 3\%-kal haladja meg az előző évi adatot (KSH, 2015). A legnagyobb termésátlag a vizsgált 5 év adatai alapján 2015-ben volt, amikor 11,33 t/ha értéket sikerült elérni (2. táblázat).

2. táblázat: A torma termőterülete és termésátlaga (2011-2015)

\begin{tabular}{|c|c|c|}
\hline Évek & Torma termésátlaga (t/ha) & Tormaterület nagysága (ha) \\
\hline $\mathbf{2 0 1 1}$ & 8,69 & 1567 \\
\hline $\mathbf{2 0 1 2}$ & 9,52 & 1601 \\
\hline $\mathbf{2 0 1 3}$ & 7,76 & 1385 \\
\hline $\mathbf{2 0 1 4}$ & 7,88 & 1313 \\
\hline $\mathbf{2 0 1 5}$ & 11,33 & 1356 \\
\hline
\end{tabular}

Forrás: KSH (2015) alapján saját szerkesztés 
A magyar torma bekerült a hungarikum termékek körébe, ami alapján európai uniós minősítést élvez. A „hajdúsági torma” az Európai Bizottság 2009. évi döntése óta eredetvédelmet élvez, vagyis Európai Uniós címkét visel (985/2009/EK rendelet, HL L 277/15). A tormatermelők alapításában létrejött a Magyar ZöldségGyümölcs Terméktanács tormatagozata is. Itt a tagok el tudták érni, hogy a növényt védetté nyilvánítsák, mivel egyetlen összefüggő termesztő körzetben foglalkoznak vele hazánk területén (I1). Egy termék hungarikum volta és eredetvédettsége alkalmas arra, hogy kifejezze annak szoros kötődését az előállítás helyéhez, illetve területéhez, és az adott termékre vonatkozó speciális tulajdonságokat, ilyen módon e termék egyediségét, megkülönböztetve azt a versenytársaktól. Ezáltal a hungarikumok és eredetvédett termékek kedvezően járulhatnak hozzá a települések és térségek fejlődéséhez (Kis-Pesti, 2015).

\section{Anyag és módszer}

Kutatásunk során primer és szekunder adatbázisokat használtunk. Az adatok kiértékelése során összehasonlító idősoros elemzést végeztünk. A statisztikai adatgyüjtés a Központi Statisztikai Hivatal (KSH) Tájékoztatási adatbázisain és STADAT tábláin, továbbá az Általános Mezőgazdasági Összeírás adatain alapul. Az idősoros vizsgálatokra alapozott kutatási eredmények alátámasztása egyszerü statisztikai eszközökkel történt. Az elemzés középpontjában a 2010-2015 közötti időszak tormatermesztése áll.

A választott téma szakirodalmi feldolgozása során a kutatási területhez szorosan kapcsolódó hazai jelentéseket, tanulmányokat és tudományos publikációkat elemeztük. A cikkben bemutatásra került különböző szakirodalmi források citálásával a Hajdúság meghatározó gyökérzöldsége, a torma. Sajnálatos módon a torma társadalmi és gazdasági helyzetével csak nagyon csekély számú hazai szakirodalom foglalkozik. A cikkben az elmúlt 5 gazdasági év adatai kerültek elemzésre és bemutatásra a termeléskor felmerülő költségek, az egyes évek értékesített termésmennyisége és az ágazat jövedelmezősége alapján időrendi sorrendben.

\section{Eredmények - A tormaágazat ökonómiai vizsgálata 5 gazdasági év adatai alapján}

\subsection{A tormatermesztés költségei}

A torma termesztése számos munkafázisra bontható, melyekhez számos költségnem tartozik. Az anyagjellegủ költségekhez tartozik a szerves trágya és mütrágya, a különböző növényvédő szerek, illetve a szaporítóanyag (dugvány), továbbá az öntözés üzemanyag költsége. A személyi jellegú kiadásokat az egyes élömunkát igénylő munkafázisok elvégzéséhez szükséges bérköltségek adják. A segédüzemi költségek körébe tartozik az összes gépi költség, melyek kivétel nélkül a bérmunka költségeivel egyeznek meg. 2015-ben a tormatermesztéshez szükséges ráfordítások mintegy 40\%-át a személyi jellegủ kiadások jelentik, a másik két 
költségcsoport, az anyagjellegủ és a segédüzemi költségek kiegyenlítetten 30-30\%ot jelentettek az összes kiadásból ( 1 . ábra).

\section{1. ábra: A költségek megoszlása költségnemenként 2015-ben}

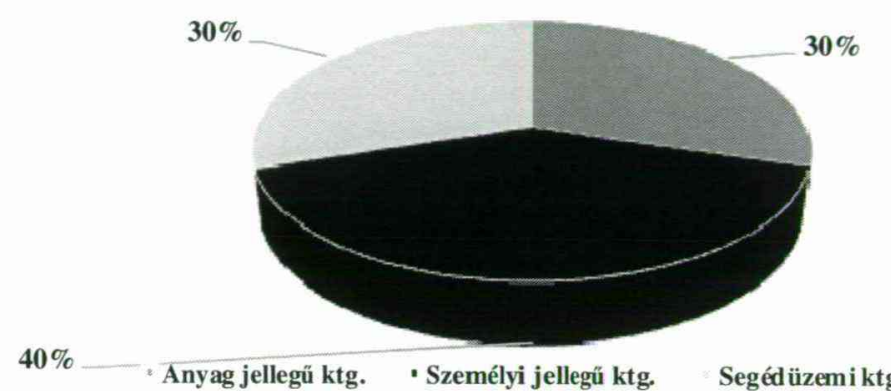

Forrás: Saját adatok (2016) alapján saját szerkesztés

A tormatermesztés költségei az elmúlt 5 év adatait elemezve, egy tonna termésre vetítve folyamatos emelkedést mutatnak. A nagyobb hozamú évek tekintetében sem feltétlenül csökken az egy tonnára jutó termelési költség. Az utóbbi években az anyagjellegủ költségekben volt mérhető a legnagyobb mértékủ növekedés. Ezt kiválóan szemléltetik a 2011-es és a 2013-as évek, amikor a betakarított torma mennyisége közel azonos volt. A két év összevetésében a közvetlen termelési jellegủ költségekben 35\%-os növekedés volt megfigyelhető. Ennek alapjául mindenekelőtt az anyagjellegủ kiadásokban bekövetkezett változások szolgálnak, melyek közül kiemelkedik a megnövelt mennyiségü kijuttatott mütrágya költsége, az öntözések számának növekedése, továbbá a gépi bérmunka ellenértékében bekövetkezett emelkedés.

3. táblázat: A tormatermesztés költségnemenkénti bontásban (ezer Ft/ha)

\begin{tabular}{|l|c|c|c|c|c|}
\hline \multicolumn{1}{|c|}{ Megnevezés } & $\mathbf{2 0 1 1}$ & $\mathbf{2 0 1 2}$ & $\mathbf{2 0 1 3}$ & $\mathbf{2 0 1 4}$ & $\mathbf{2 0 1 5}$ \\
\hline Anyagjellegú ktg. & 147 & 300 & 270 & 332 & 277 \\
\hline Személyi jellegú ktg. & 299 & 299 & 328 & 375 & 375 \\
\hline Segédüzemi ktg. & 225 & 290 & 279 & 291 & 282 \\
\hline Összes közvetlen ktg. & 672 & 890 & 878 & 998 & 935 \\
\hline Általános ktg. & 67 & 89 & 87 & 99 & 93 \\
\hline Termelési ktg. & 739 & 979 & 966 & 1098 & 1028 \\
\hline
\end{tabular}

Forrás: Saját adatok (2016) alapján saját szerkesztés

A segédüzemi költségek jelentik a teljes termelési költség 30-40\%-át. A gépi munkák három szakaszra oszthatóak. Az első szakaszt a talajelőkészítés, az alaptrágya kijuttatása és a bakhátkészítés munkamúveletei jelentik. 2012-ben az alaptrágyák kijuttatásának költsége az általunk is vizsgált gazdaságban az évi segédüzemi költségek 13\%-át, a tavaszi gépi költségek $28 \%$-át tették ki. A munkagéppel végzett szántás munkadíja 29988 Ft/hektár volt 2015-ben, ami 20\%- 
os növekedés a 2011-es évi 24920 Ft/hektár díjhoz képest. A bakhátkészítést egy helyi mezőgazdasági szolgáltató végzi, aki kifejezetten a torma gépi szolgáltatására szakosodott. A költségei jelentősen meghaladják a szántás díját. A 2011-es költség $50400 \mathrm{Ft}$ /hektár volt, ami 2015-re 10\%-kal emelkedve hektáronként $56000 \mathrm{Ft}$ lett. A bakhátképzés a tavaszi bérmunkák költségkeretének mintegy 50-60\%-át teszik ki. Összességében a 2015-ös évben a tavaszi munkálatok az összes gépi költség $35 \%$-át jelentették.

A tormatermelés második szakaszába a nyári növényápolási munkák, a sorközmủvelés, a növényvédelemi munkák tartoznak. A sorközmüvelést a vegetációs időszakban több alkalommal is el kell végezni. A vizsgált gazdaságban a 2013-as évben 4 alkalommal került sor sorközmúvelö kultivátor alkalmazására a gyomok felszaporodása miatt, így a 2012-es évhez képest 40\%-kal nagyobb kiadást eredményezett ez a munkafázis.

Az elmúlt években növekedett a szükséges növényvédelmi kezelések száma (4 alkalom/év). Az ápolással kapcsolatos munkák költségei 2015-ben a teljes gépi jellegü kiadások $28 \%$-át tették ki.

A tormatermelés harmadik szakaszában kerül sor a segédüzemi költségek, a betakarításkor felmerülö munkaműveletek, levelezés, a gépi rizómakiemelés, a telephelyre és az átvevőhelyre való szállítás bérköltségeinek elszámolására. A gépi kiemelés a teljes segédüzemi költség 20\%-át adta 2015-ben. 2011-ben egy hektár kiemeléséért még $50400 \mathrm{Ft}$-ot kértek, mely 2015-re már $56000 \mathrm{Ft} /$ hektárra emelkedett. 2015-ben az öszi munkák részaránya az összes gépi költségböl $34 \%$ volt.

A termesztés kézi munkát igénylő fázisaihoz a vizsgált gazdaság helyi idénymunkásokat alkalmazott. Az alkalmazottak számára kifizetett bér jelenti a személyi jellegủ kiadásait, mely az összes közvetlen költség 40\%-a. A személyi jellegú kifizetéseket is 3 szakaszra lehet osztani a gépi költségek felosztásával azonos csoportosítás szerinti időszaki bontással. Az első szakaszra esik a dugvány előkészítésétől a kiültetésig tartó munkafolyamat. Ez a termelés egyik legfontosabb fázisa. Egy hektár szaporítóanyag elökészítésének, megvágásának az ideje 80 munkaóra. Az ültetés munkaidő igénye egy hektárra vetítve 120 munkaóra, 2015ben ez adta a személyi jellegú költségek 30\%-át. A kézi munkák második szakaszában kerül sor a torma hajtásválogatására és a mechanikai gyommentesítésére. A fejelés munkaidő szükséglete 80 munkaóra. A kapálásra egy vegetációs idöszakon belül több alkalommal is szükség lehet. Egy szezonban átlagosan 40 munkaórát lehet tervezni ezekre a folyamatokra. 2015-ben a második szakasz jelenti a személyi jellegü kifizetések 18\%-át. A fizikai élőmunkák legköltségesebb része az öszi betakarítás időszaka, ennek része a gyökerek összeszedése, csomóba rakása, szállítójármüre való rakása.

A torma elökészítése során szedik ki a következő évi termelés megkezdéséhez szükséges szaporítóanyagot, valamint ekkor kerül sor a torma osztályozására is. 2015-ben a kézi felszedés 105 munkaórát, az áru elökészítés 240 munkaórát vett igénybe, mely az összes személyi jellegü ráfordítás $52 \%$-át képezte. A bérmunkák után fizetendő járulékok 2013-ban a személyi jellegü kiadásokban 9\%-os, 2014 óta 
14\%-os emelkedést eredményeztek. 2012-es évhez képest 2014-re 25\%-kal növekedtek a személyi ráfordítások.

A 2011-es költségeket kedvezően befolyásolta, hogy az ideális időjárási körülmények miatt nem kellett öntözni, viszont az azt követő években az öntözések száma megnött, 2015-ben már az összes anyagjellegü költség 36\%-át ez a tétel adta. 2015-ben a közvetlen költségek 30\%-át tették ki az anyagjellegü kiadások.

\subsection{A tormatermesztés bevételei}

A termesztésünk elsődleges célja, a minél nagyobb hektáronkénti hozamok elérése, a minőség megtartása mellett. 2011-2015 között a vizsgált gazdaság az alábbi hozamokat érte el hektáronként a termésminőségi osztályonkénti bontásban (4. táblázat).

\section{4. táblázat: A betakarított (értékesített) hektáronkénti mennyiség 2011-2015} közötti években (kg/ha)

\begin{tabular}{|c|c|c|c|c|c|}
\hline Minőségi osztályok & 2011 & 2012 & 2013 & 2014 & 2015 \\
\hline I. o. torma & 5738 & 7590 & \multirow{4}{*}{7197} & \multirow{4}{*}{8331} & 5300 \\
\hline II. o. torma & 678 & 722 & & & 840 \\
\hline III. o. torma & 414 & 479 & & & 280 \\
\hline IV. o. torma & 1011 & 926 & & & 650 \\
\hline Torma gyökér & 662 & 1416 & 1184 & 893 & 540 \\
\hline Összesen & 8503 & 11133 & 8381 & 9224 & 7610 \\
\hline
\end{tabular}

Forrás: Saját adatok (2016) alapján saját szerkesztés

A vizsgált gazdaság 2013-ban és 2014-ben ömlesztetten értékesített, nem végzett válogatást. 2011, 2012 és 2015 évben a termés mintegy 70-80\%-át az első osztályú rizóma tette ki. A vizsgált gazdaság összesített hozamait alapul véve a legjobb év a 2012-es, míg a legrosszabb pedig az aszályos 2015-ös év volt. A tormának minőségi osztályonként eltérő a felvásárlási egységára, melynek a 20112015 közötti időszakban történt változásait az 5. táblázat szemlélteti.

5. táblázat: A torma felvásárlási egységára minőségi osztályonként (Ft/ kg)

\begin{tabular}{|l|c|c|c|c|c|}
\hline Minóségi osztályok & $\mathbf{2 0 1 1}$ & $\mathbf{2 0 1 2}$ & $\mathbf{2 0 1 3}$ & $\mathbf{2 0 1 4}$ & $\mathbf{2 0 1 5}$ \\
\hline I. o. torma & 299 & 180 & & & 350 \\
\cline { 1 - 3 } II. o. torma & 250 & 159 & \multirow{2}{*}{186} & \multirow{2}{*}{263} & 250 \\
\cline { 1 - 2 } \cline { 1 - 2 } III. o. torma & 80 & 100 & & & 150 \\
\hline IV. o. torma & 40 & 40 & & & 80 \\
\hline Torma gyökér & 20 & 20 & 15 & 20 & 30 \\
\hline
\end{tabular}

Forrás: Saját adatok (2016) alapján saját szerkesztés

Az 5. táblázat adatai alapján az egymást követő években jelentős árváltozások történtek. A vizsgált gazdaság 2013-ban és 2014-ben egységesen értékesítette a terményt: a 2013-as $186 \mathrm{Ft} / \mathrm{kg}$ egységárhoz képest 2014-re 41\%-os árnövekedés következett be. Az osztályonként megszabott árak esetén a legnagyobb érték az első osztályú tormához kapcsolódik. Ez 2015-ben volt a legmagasabb $350 \mathrm{Ft} / \mathrm{kg}$ 
egységárral, ami a 2012. évben fizetett felvásárlási ár duplája, mivel abban az évben jelentős túltermelés volt megfigyelhető a piacon. A felvásárlási egységárak erősen függnek a megtermelt mennyiségtől, a külföldi piacok keresletétől, a feldolgozóipar adott évi igényeitől és - talán a legnagyobb mértékben - a kereskedőktől. A 6. táblázat minőségi osztályonkénti bontásban tartalmazza az ágazat bevételeit.

\section{6. táblázat: A tormatermesztés bevételei minőségi osztályok szerint (ezer $\mathbf{F t} / \mathbf{h a})$}

\begin{tabular}{|c|c|c|c|c|c|}
\hline Minőségi osztályok & 2011 & 2012 & 2013 & 2014 & 2015 \\
\hline I. o. torma & 1716 & 1336 & \multirow{4}{*}{1337} & \multirow{4}{*}{2190} & 1855 \\
\hline II. o. torma & 169 & 115 & & & 210 \\
\hline III. o. torma & 33 & 48 & & & 42 \\
\hline IV. o. torma & 40 & 37 & & & 52 \\
\hline Torma gyökér & 13 & 28 & 17 & 17 & 16 \\
\hline Árbevétel összesen & 1972 & 1594 & 1355 & 2208 & 2175 \\
\hline Támogatás & 70 & 70 & 70 & 70 & 150 \\
\hline Termelési érték & 2042 & 1664 & 1425 & 2278 & 2325 \\
\hline
\end{tabular}

Forrás: Saját adatok (2016) alapján saját szerkesztés

Az első osztályú rizóma a betakarított mennyiség 75-80\%-át teszi ki. Mivel a legmagasabb felvásárlási árat is ezért az osztályért fizetik, a termelési érték legnagyobb hányadát is ez a minőségi osztály jelenti, a bevételek közel 80-90\%-át. A vizsgált gazdaság árbevételét és a termelési értékeit vizsgálva megállapítható, hogy 2015-ben kapták a legtöbbet és 2013-ban a legkevesebbet a termény után. A vizsgált időszak legnagyobb növekedését a 2014-es évben érte el a gazdaság, amikor az előző évi bázishoz viszonyítva a termelési érték 60\%-os növekedést mutatott. A 2014-es árbevétel 1,5\%-kal haladta meg a 2015-ös értéket a vizsgált gazdaságban, viszont a 2015-ös termelési érték 2\%-kal múlta felül az előző, 2014es év hasonló értékét. A termelési érték és az árbevétel közötti eltérések oka a támogatások összegében bekövetkezett változásokban keresendő. 2014-ig a támogatás mértéke hektáronként 70000 Ft volt, 2015-ben azonban egy hektárnyi tormaterület után $150000 \mathrm{Ft}$ támogatás volt igényelhető. A támogatás a termelési érték 7\%-át tette ki 2015-ben, míg a legrosszabb 2013-as évben csak 5\%-át. A második legeredményesebb évben, 2014-ben a termelési érték 3\%-át tette ki a támogatás. A vizsgált gazdaság esetén a termelési érték elsösorban tormaértékesítésből származik, a támogatás összege pedig többletbevételként jelenik meg.

\subsection{A tormatermesztés gazdasági eredményessége}

A vizsgált gazdaság eredményeinek és hatékonysági mutatóinak elemzése elengedhetetlenül fontos annak érdekében, hogy reális képet kapjunk a tormatermesztéssel elérhető előnyökről. A korábban már bemutatott ágazati kihívások (például az utánpótlás nehézkessége, a nehéz fizikai munka riasztó hatása) teljes mélységü feltárása mellett elemezni kell a torma termesztésének 
$90 \bullet$ Harangi-Rákos M. - Zilahi K. - Novák N. - Oláh J. - Popp J.

eredményességét. A vizsgált 5 év adatainak elemzése az alábbi eredményeket hozta (7. táblázat).

7. táblázat: A tormatermesztés eredményei (ezer Ft/ha)

\begin{tabular}{|l|c|c|c|c|c|}
\hline Megnevezés & $\mathbf{2 0 1 1}$ & $\mathbf{2 0 1 2}$ & $\mathbf{2 0 1 3}$ & $\mathbf{2 0 1 4}$ & $\mathbf{2 0 1 5}$ \\
\hline Árbevétel & 1972 & 1594 & 1355 & 2208 & 2175 \\
\hline Támogatás & 70 & 70 & 70 & 70 & 150 \\
\hline Termelési érték & 2042 & 1664 & 1425 & 2278 & 2325 \\
\hline Közvetlen ktg. & 672 & 890 & 879 & 998 & 935 \\
\hline Fedezeti összeg & 1370 & 774 & 546 & 1280 & 1390 \\
\hline Általános ktg. & 67 & 89 & 87 & 100 & 93 \\
\hline Termelési ktg. & 740 & 980 & 966 & 1098 & 1028 \\
\hline Nettó jövedelem & 1302 & 685 & 458 & 1180 & 1296 \\
\hline
\end{tabular}

Forrás: Saját adatok (2016) alapján saját szerkesztés

A fedezeti összeg értékét a termelési érték és a közvetlen költségek közötti különbség jelenti, ami a vizsgált vállalat esetén 2012-ben és 2013-ban mutatta a két legalacsonyabb értéket. A legnagyobb fedezeti összeget 2015-ben érték el, ami 2,5szer haladta meg a leggyengébb, 2013-as év hasonló értékét.

A gazdaság profitját adó nettó jövedelem értékét a termelési érték és az összes termelési költség különbözete eredményezi. A nettó jövedelem értéke a fedezeti összeg mértékénél az általános költségek összegével kisebb. A vizsgált gazdaság legjövedelmezőbb éve a 2011-es esztendó volt, amely a legkevésbé jövedelmező, 2013. év jövedelmének közel 3-szorosát hozta. A tormaágazat jövedelmezősége - a vizsgált gazdaság adataival alátámasztva - nagy ingadozást mutat. Az ágazat és vele együtt a vizsgált gazdaság is a piaci szereplök számára rendkívül kiszolgáltatott. A hozam növekedése kizárólag akkor érhető el, ha a ráfordítások mértékét is növelni lehet. A hozamnövekedés nem automatikusan jelent jövedelemnövekedést, amit jól példáz a 2011-es és a 2014-es évek adatainak összehasonlítása. 2014-ben a hozam, mintegy 8,5\%-kal meghaladta ugyan a 2011 ben betakarított hektáronkénti mennyiséget, és az átlagár is magasabb volt, a nettó jövedelem mégis $10 \%$-kal alacsonyabb lett. Ennek magyarázata, hogy a 2014-es termelési érték, a hozam és árváltozás eredójeként, 11,5\%-kal haladta meg a 2011. évi értéket, mindeközben a termelési költség ennél nagyobb mértékben, $48 \%$-kal nött.

8. táblázat: Az ágazat hatékonysági mutatói

\begin{tabular}{|l|c|c|c|c|c|}
\hline Megnevezés & $\mathbf{2 0 1 1}$ & $\mathbf{2 0 1 2}$ & $\mathbf{2 0 1 3}$ & $\mathbf{2 0 1 4}$ & $\mathbf{2 0 1 5}$ \\
\hline Fötermék önköltség (Ft) & 84,2 & 99,0 & 131,9 & 129,7 & 133,7 \\
\hline Költségarányos jövedelmezőség (\%) & 176,1 & 70,0 & 47,4 & 107,4 & 126,1 \\
\hline Jövedelemszint (\%) & 63,8 & 41,2 & 32,2 & 51,8 & 55,8 \\
\hline Költségszint (\%) & 36,2 & 58,8 & 67,8 & 48,2 & 44,2 \\
\hline
\end{tabular}

Forrás: Saját adatok (2016) alapján saját szerkesztés 
A vizsgált gazdaság fötermékének önköltsége, a 2014. év kivételével folyamatos emelkedést mutatott a felmért időszakban (8. táblázat). Amennyiben a gazdaság költségarányos jövedelmezöségét is vizsgáljuk, ez a megállapítás nem helytálló, hiszen a vizsgált évek között jelentös eltérések figyelhetők meg. Költségarányos jövedelmezőség tekintetében a vizsgált gazdaság 2011-ben tudta a legjobb eredményt elérni, amikor $100 \mathrm{Ft}$ ráfordítás mellett $176 \mathrm{Ft}$ jövedelmet tudtak előállítani.

\subsection{A torma hazai feldolgozása és piaci helyzete}

A termesztő tájegységen előállított tormamennyiség helyi felvásárlók és közvetítők közremüködésével jut el a termelőktől a feldolgozóüzemekbe. A Magyarországon termesztett tormamennyiség mindössze 18,6\%-a kerül a magyarországi feldolgozóipar valamelyik egységébe. A Magyarországon termelt torma nagyobb hányada, mintegy 80-85\%-a kerül export keretében külföldi piacokra. A kivitel 60\%-a irányul kelet- és kelet-közép-európai országokba, például Lengyelországba vagy Romániába, míg a kivitel további 40\%-a nyugati piacokra, elsődlegesen Németországba és Svájcba. Az utóbbi években számos vállalat foglalkozott és foglalkozik tormakereskedelemmel, de ezek közül csak néhány tekinthetö a tormapiac kiemelkedő szereplöjének. A piacon található 5 legjelentősebb szereplö együttesen a megtermelt torma 70\%-át vásárolja fel annak érdekében, hogy azt tovább értékesíthessék vagy feldolgozhassák. A felvásárlási árakat tekintve attól függetlenül sincs eltérés a cégek között, hogy azok eltérö felvásárlási módszert alkalmaznak. Míg az egyik cég ömlesztve vásárolja fel a tormát, addig a másik kizárólag minőségi osztályozás szerint zsákolt formában. A megtermelt tormamennyiség 30\%-a kisebb cégekhez kerül.

\section{Következtetések, javaslatok}

A tormatermesztési ágazat jelentős költségtételekkel rendelkezik, és amennyiben a termesztés technológiája nem tud fejlődni, a nagyobb hozam elérése érdekében a költségek további emelkedése prognosztizálható. A torma termesztése kapcsán jelentkező kiadások legjelentősebb hányadát, közel 40\%-ot a személyi jellegü költségek jelentik. A termesztés továbbra is magas élőmunka igény mellett valósul meg, melynek változására rövidtávon nem látszik esély. Az egyik legfontosabb kihívás a munkaerő hiánya lesz, ami vagy a teljes gépesítéshez fog vezetni vagy az ágazat méretének a stagnálását, esetleges csökkenését fogja okozni.

A termesztéssel elérhető bevételek függenek a termés hozamától, annak minőségétöl és a piaci áraktól is. A magas hozamokat és a minőséget jelentősen befolyásolni tudják a külső környezeti tényezök, de a kedvezőtlen hatások megfelelő agrotechnikai beavatkozással részben vagy teljesen korrigálhatóak. A piaci árak befolyásolására a termelök nem képesek, más piaci szereplőktől, elsősorban a felvásárlóktól és a külföldi feldolgozóktól függnek. A szektor reformjának első lépéseit a termelöknél lenne célszerü végrehajtani. A termesztés bizonyos munkafázisainak, így az ültetés és a betakarítás további gépesítésével, az 
élőmunka-igény csökkentésével lehetne elörelépést elérni, de kizárólag abban az esetben, amennyiben ez nem eredményezi a minőség romlását.

Tekintettel arra, hogy a hazai termésnek mindössze 18\%-át dolgozzák fel hazai üzemekben és a tormatermés nagyobb hányada külföldi piacokra kerül, az árakat a külföldi üzemek szabják meg. A megoldást a hazai feldolgozóipar bövítése jelentheti.

\section{Irodalomjegyzék}

Géczi L. (2003): A torma termesztése. Östermelők gazdálkodók lapja 1. szám, 84-86.

Géczi L. (2007): A torma ültetése. Kertészet és Szólészet, 56:(22), 10-11.

Géczi L. (2009): A torma hajtásválogatása. Kertészet és Szólészet, 58:(29), 14.

Géczi L. (2009): A tormából élnek. Kertészet és Szólészet, 58:(34), 12-14.

Géczi L. (2011): A torma tápanyagellátása. Kertészet és Szólészet, 60:(11), 10-11

Géczi L. (2013): A torma termesztése. Mezőgazda Kiadó, Budapest.

Haraszthy J. (2005): A torma. Piremon Nyomdauizem, Vámospércs.

I1: A hajdúsági torma - Hungarikum. <http://jomagyararu.karahun.hu/hungarikum-magyarelelmiszer/noveny/a-hajdusagi-torma----hungarikum> (2016.10.02.)

Kapronczai I. (2011): A magyar agrárgazdaság az EU csatlakozástól napjainkig. Szaktudás Kiadóház, Budapest.

Kis K., Pesti K. (2015): Szegedi élelmiszeripari hungarikumok helyzete, lehetőségei a globalizáció és a lokalizáció kölcsönhatásában: eredet, hagyomány és minőség szögediesen. Jelenkori Társadalmi és Gazdasági Folyamatok, 10:(2), 9-34.

KSH (2015): Fontosabb szántóföldi növények és zöldségfélék, valamint a gyep és a nád terméseredményei, 2009-től <http://statinfo.ksh.hu/Statinfo/haViewer.jsp>

KSH (2016a): A mezőgazdaság szerepe, a nemzetgazdaságban 2015. <http://www.ksh.hu/docs/hun/xftp/idoszaki/mezo/mezoszerepe15.pdf>

KSH (2016b): Statisztikai tükör <http://www.ksh.hu/docs/hun/xftp/gyor/vet/vet1606.pdf>

KSH (2016c): Földhaśználat müvelési ágak és gazdaságcsoportok szerint (1990-). <http://www.ksh.hu/docs/hun/xstadat/xstadat_eves/i_omf001a.html>

Magda S. (2003): Kertészeti ágazatok szervezése és ökonómiája. Szaktudás Kiadóház, Budapest.

Németi L. (2003): A magyar agrárgazdaság az ezredfordulón. Szaktudás Kiadóház, Budapest.

Pántya J. (2000): A Debrecen környéki tormatermesztés néprajza. Kapitális Bt., Debrecen.

Potori N. (szerk.), Udovecz G., Popp J., Csikai M. (2008): A versenyesélyek javitásának lehetőségei a magyar élelmiszer-gazdaságban. Szaktudás Kiadóház, Budapest.

Slezák K. (2005): A torma ápolási munkái. Kertészet és szölészet, 54:(13), 21.

Takácsné György K., Takács I. (2016): A magyar mezőgazdaság versenyképesége a hatékonyságváltozások tükrében. Gazdálkodâs, 60:(1), 31-50. 